How Low Business Tax Rates Attract

Multinational Headquarters:

Municipality-Level Evidence from Germany

Sascha O. Becker

Peter H. Egger

Valeria Merlo

Stirling Economics Discussion Paper 2008-30

December 2008

Online at http://www.economics.stir.ac.uk 


\title{
How Low Business Tax Rates Attract Multinational Headquarters: Municipality-Level Evidence from Germany*
}

\author{
Sascha O. Becker, ${ }^{\dagger}$ Peter H. Egger ${ }^{\ddagger}$ and Valeria Merlo ${ }^{\S}$
}

December 18, 2008

Abstract

Most existing empirical evidence on the impact of profit taxation on multinational firm activity is based on cross-country data. One major drawback of such data is that countries differ not only with regard to taxes but along other dimensions which might be hard to capture by means of observable characteristics. We compile a database of more than 11,000 municipalities in Germany to analyze the sensitivity of the location decisions of foreign MNEs with respect to business tax rates which are levied directly by the municipalities. Using count data models suited for cross-sectional and panel data, we find that higher business tax rates have a negative effect on the number of foreign MNE headquarters, after controlling for other determinants of firm location decisions. On average, a one-percent reduction of the municipal business tax rate (equivalent to a decline by about 0.14 percentage points) leads to an increase in the number of headquarters of foreign MNEs by about 0.05 . Hence, the average municipality needs to reduce its business tax rate by $20 \%$ to attract one foreign MNE.

Key words: Multinational firms; Profit taxation; Regional public finance; Count data.

JEL classification: F23, H25, H32, R10.

*Acknowledgments: We thank Thiess Büttner and participants at the Deutsche Bundesbank FDI Workshop, and at the MGSE and CES seminars at LMU Munich for useful comments and discussions. We thank Elisabetta Fiorentino, Heinz Herrmann, and Alexander Lipponer for support at the Deutsche Bundesbank. Merlo thanks the German Science Foundation for funding.

$\dagger$ Affiliation: U Stirling, Ifo, CESifo and IZA. E-mail: sascha.becker@stir.ac.uk.

${ }^{\ddagger}$ Affiliation: Ifo, LMU Munich, WIFO, CESifo, and GEP. E-mail: egger@ifo.de.

$\S$ Affiliation: Ifo and LMU Munich. E-mail: merlo@ifo.de. 


\section{Introduction}

A sizeable literature in theoretical public finance argues that the location of capital in general and that of multinational enterprises (MNEs) in particular reacts sensitively to profit tax policy (Wilson, 1987; Janeba, 1995; Huizinga and Nielsen, 1997; Haufler and Wooton, 1999; Wilson, 1999; Ludema and Wooton, 2000; Davies, 2003, 2005; Devereux and Hubbard, 2003; Baldwin and Krugman, 2004; Raff, 2004; Borck and Pflüger, 2006; Bucovetsky and Haufler, 2008; by no means, this list is exhaustive). When lumpy investment - i.e., firm or plant location - is sensitive to profit taxation, many of these models predict a race to the bottom in profit tax rates so that, in equilibrium, countries have to offer a profit tax rate of zero to attract investors. Otherwise, a jurisdiction will lose the whole profit tax base to its competitors. One key reason for this outcome is that - in most of the traditional models of tax competition - countries differ only in terms of profit taxes or, more precisely, low profit taxes are the only attraction governments may offer to firms.

Empirically, there is hardly any evidence of a race to the bottom in profit taxes (except for the existence of a few small tax havens). Therefore, recent theoretical work suggested mechanisms to avoid the knife-edge case of a race to the bottom in tax rates. The New Economic Geography literature hypothesizes that there are factors generating agglomeration economies which, in turn, reduce the sensitivity of location decisions of foreign MNEs with respect to profit (or capital) taxation (Ludema and Wooton, 2000; Baldwin and Krugman, 2004; Borck and Pflüger, 2006). More generally, taxes are only one factor affecting firm location. There is little reason for a municipality to eliminate profit taxes provided that the overall environment - e.g. available infrastructure and human capital endowment of the work force makes it attractive enough to locate there.

It is by now well documented in empirical research at various levels of aggregation (firms, industries, and aggregate bilateral activity) that the location of MNE activity across countries inter alia depends on national profit tax policy (Devereux and Griffith, 1998; de Mooij and Ederveen, 2003, 2006, 2009; Blonigen and Davies, 2004; Grubert and Mutti, 2004; Huizinga and Nicodème, 2006; Egger, Pfaffermayr, Loretz, and Winner, 2008; Overesch and Wamser, 2008). However, there are two concerns with previous work. First, for some countries, such as Germany or Switzerland, the (unique) profit tax rate is an artifact, since tax authorities at the sub-national level may determine taxes on profits in their jurisdiction. Second, countries differ 
in many ways rather than only in profit taxes, most importantly with regard to institutional characteristics that are hard to measure. Omission of relevant institutional determinants of MNE activity is likely in cross-country studies and may bias empirical estimates of the sensitivity of MNE activity with respect to taxation and other variables. Both problems can be avoided when considering firm location decisions at the sub-national level. Of course, a prerequisite for this is the existence of sub-national jurisdictions which differ with regard to profit tax rates.

There is a small literature on the nexus between firm births (national and foreign firms) and taxation which focuses on location decisions across regions within a country. For instance, Slemrod (1990; analyzing direct investments in 50 U.S. states by home country) Papke (1991; exploiting information across 22 U.S. states), Hines (1996; analyzing foreign direct investment in 50 U.S. states by home country), List (2001; using 58 Californian counties), and Brühlhart, Jametti, and Schmidheiny (2007; focusing on 213 large Swiss municipalities) belong here. Of these studies, only Slemrod (1990), Hines (1996), and List (2001) focus on the location decisions of foreign firms (i.e., foreign MNEs) explicitly and, hence, ask questions which are comparable to ours. List (2001) analyzes the impact of the per-capita property tax rate on MNEs rather than a profit tax burden which is directly levied on businesses. Slemrod (1990) and Hines (1996) are interested not only in the impact of state-level corporate tax rates in the U.S. but also at the role of the system of double taxation relieve in the recipient countries. Apart from the differences in the research questions posed in this paper as compared to the papers just mentioned, the number of jurisdictions (i.e., the number of host locations) which we can analyze is larger than in previous work by more than one order of magnitude.

We compile a large data-set on local business tax rates $^{1}$ and other data at the municipality level. Our data covers more than 11,000 German municipalities over the period 2001 to 2005. We link this data-set with data on the location of the German headquarters of foreign MNEs. ${ }^{2}$ The set of

\footnotetext{
${ }^{1}$ These business tax rates are set directly by municipalities, and they apply to the profits of all firms in a jurisdiction. For exceptions, see $\S 3$ of the German business tax law (Gewerbesteuergesetz GewStG).

${ }^{2}$ The work of Slemrod (1990) and Hines (1996) blends home country and host jurisdiction issues with corporate taxation. Unlike them, we do not distinguish foreign MNEs according to their country of origin. We prefer to focus on the responsiveness of MNE location (from anywhere) to host jurisdiction business tax rates for two reasons. First, we
} 
locations (municipalities) considered here is much more homogeneous than in cross-country data. For instance, in contrast to an international setting, other tax parameters such as taxes on income are identical across German municipalities since they are levied at the level of the federal union. Moreover, sub-national data allow one to control for the heterogeneity of locations within countries which is more difficult with national data.

The location of regional headquarters is important because they are typically tied to the main production plants in the same municipality. Attracting a regional headquarters of a foreign MNE to a municipality thus promises jobs and local business tax income. There is anecdotal evidence of municipalities which lower their tax rates so as to explicitly attract foreign firms. One well-known example is the small town of Holzkirchen, close to Munich in Upper Bavaria, that lowered its business tax rate to appeal to Sandoz, a big pharmaceutical firm. ${ }^{3}$ Another example constitutes the municipality of Amering which managed to lure Kathrein, the world leader in satellite dishes, to locate its headquarters there, by lowering its local business tax rate. ${ }^{4}$ We would be able to provide further examples, but these are enough to illustrate how local business tax rates may affect a firm's location choice.

The majority of municipalities in Germany does not attract any foreign headquarters, however. This could be to do with (high) business tax rates as well as other factors. We will argue that (low) business tax rates alone are not enough to attract foreign headquarters for the average municipality. Econometrically, the fact that numerous municipalities are incapable of attracting any foreign MNE headquarters suggests that the problem of interest may not be approached appropriately by a linear regression model. Moreover, many of the municipalities which successfully attract foreign MNEs

are interested in how a given number of foreign investments to just one country (Germany) is allocated within the country in response to tax rates. Hence, we disregard multilateral considerations of investors - e.g., decisions related to whether invest in Germany at all. Second, the huge number of host jurisdictions involves a relatively large fraction of municipalities where no investment is undertaken at all. The fraction of zeros would necessarily rise more than proportionately if we distinguished the number of investors by their country of origin. This would call into question the applicability of some of the methods applied here. Hence, we have to relegate questions related to the origin of foreign investments with this data-set to another paper.

${ }^{3}$ See http://www.sueddeutsche.de/wirtschaft/artikel/10/51958/ reporting that Holzkirchen had lowered its local business tax rate by 30 percent, making it the second-lowest in the state of Bavaria, in its (successful) attempt to attract Sandoz.

${ }^{4}$ See http://www.kathrein.de/de/presse/cont/texte2005/pi0553.htm. 
host only a small number of headquarters. Therefore, we employ count data models to estimate the impact of business taxation on the number of foreign MNE headquarters located in a municipality, controlling for other determinants such as population characteristics, the skill level of the work force, and geographical characteristics. More specifically, we estimate cross-sectional and panel data models, where business tax rates are treated as exogenous or endogenous. Across the board, we identify a negative impact of business tax rates on the number of MNE headquarters in a municipality which is significantly different from zero. The magnitude of the impact seems reasonable: a reduction of one percent of the municipal tax rate is related to an increase in the expected number of headquarters hosted by the municipality of about $450 \%$ in the preferred model. For the average municipality, the latter is equivalent to an increase in the number of foreign MNE headquarters by 0.05 . In other words, the average municipality would have to lower its business tax rate by about $20 \%$ (or 2.8 percentage points) to attract only one headquarters of a foreign MNE. When accounting for the endogeneity of tax rates the marginal impact of business taxation is somewhat higher.

The remainder of the paper is organized as follows. We summarize the literature on determinants of regional headquarters in section 2. Section 3 describes features of the data-set. Section 4 introduces the empirical strategy for the analysis of the impact of business taxes on the number of MNE headquarters in a municipality. Section 5 summarizes the empirical findings from both cross-section and panel data analysis. The last section provides some concluding remarks.

\section{Determinants of MNE regional headquar- ters location}

In our empirical analysis, we estimate parsimonious models of the number of regional headquarters set up in German municipalities. As suggested by previous research on the impact of profit (or capital) taxation on lumpy investment decisions by MNEs, we expect higher business tax rates levied by municipalities to exert a negative impact on the number of headquarters. However, to isolate their role on MNEs' location decisions, we have to control for other key explanatory variables suggested by the literature. These are the following. 
According to a sizable body of work in theoretical international economics, knowledge-capital embodied in skilled workers is one of the key determinants of MNE activity (see Markusen, 2002). In accordance with that line of reasoning, empirical research identified a key role of the local supply of skilled labor to play for the set-up of MNE headquarters (see Carr, Markusen, and Maskus, 2001; Markusen and Maskus, 2002; Blonigen, Davies, and Head, 2003). While previous evidence is available for investment (and foreign affiliate sales) at the national level, similar arguments ought to hold for headquarters location within a country. Our skill measure is the share of workers with tertiary school education.

A second key factor determining MNE activity according to previous research is host country location size (see Markusen, 2002; Barba Navaretti and Venables, 2004). Using country (or country-pair) data in previous empirical work, host country location size is typically controlled for by variables based on gross domestic product (GDP). However, GDP is not available (as well as endogenous) at regionally very disaggregated levels. For this reason, in our preferred specification, we include population density, the independency ratio of the population (i.e., the number of people aged between 15 and 65 years as a fraction of total population in the region) and geographical area. ${ }^{5}$ Notice that - once including log geographical area as well - we may interpret the coefficient of $\log$ population density as reflecting the elasticity with respect to population size. The independency ratio is the best measure available to capture the relative size of the working-age population in a region. Including $\log$ area along with population density also approximates land prices and provides a measure of the relative abundance of land as such, which may be used relatively intensively in some of the sectors MNEs operate in..$^{6,7}$

\footnotetext{
${ }^{5}$ One might think of distance to a metropolitan area as a further possible determinant. However, this is highly correlated with geographical area and population in the crosssection, and it is wiped out by the method applied with panel data. Therefore, we do not include this variable.

${ }^{6}$ There are various ways of specifying these influences. For instance, it turns out that including log population and log area obtains similar results to the ones with the preferred specification, where we use population density and $\log$ area. Similarly, using the area covered with buildings and streets (instead of log total geographical area) along with the $\log$ share of area reserved for building obtains similar results. However, in our preferred specification, multi-collinearity between the regressors is reduced to the largest possible extent.

${ }^{7}$ Another strand of research includes market potential - i.e., some inverse-trade-costweighted average of market size of other regions as a determinant of firm location (see
} 
Research at the aggregate level has further pointed to the role of physical capital for MNEs' plant set-up (see Bergstrand and Egger, 2007). Since data on capital stocks are not available at the regional level, the best we can do to proxy for capital is to include log gross investment share (in total expenditures) of a municipality. In line with previous theoretical work, we expect that larger gross investments - reflecting bigger local stocks of capital in equilibrium - positively affect the inclination of foreign MNEs to locate their regional headquarters in a municipality. For similar reasons, we include the fraction of land area covered with infrastructure (buildings and streets).

Finally, we may be concerned about structural differences between Western and Eastern German municipalities in their ability to attract foreign MNEs' headquarters. To capture the latter, we include an indicator variable which takes a value of zero for municipalities in the former Western Germany and a value of one for municipalities in the New Länder. ${ }^{8}$ Since the available infrastructure in Germany's New Länder was and still is of a lower quality, on average, in the sample period, we expect the parameter of this variable to take a negative sign.

\section{Data}

The data on the count of multinational firms per municipality come from Deutsche Bundesbank's Micro-Database Direct Investment (MiDi). All German firms with a balance sheet total of more than 3 million Euros in which foreign investors hold $10 \%$ or more of the shares or voting rights are required by law to report to the Deutsche Bundesbank balance sheet information as well as information on the sector, legal form, and number of employees. ${ }^{9}$ In-

Head and Mayer, 2004). However, we employ such a population-based variable as an instrument for business tax rates in some of the empirical models. The respective tests do not reject this choice as compared against a model which includes weighted population of neighboring regions as a direct determinant of the number of foreign MNE headquarters located in a municipality.

${ }^{8}$ Overall, Germany consists of 16 Länder. Of those, the following 11 are located in the former Western German part of the country (the Old Länder): Baden-Württemberg, Bayern, Berlin, Bremen, Hamburg, Hessen, Niedersachsen, Nordrhein-Westfalen, RheinlandPfalz, Saarland, and Schleswig-Holstein. The following 5 Länder are located in the former Eastern German part of the country (the New Länder): Brandenburg, MecklenburgVorpommern, Sachsen, Sachsen-Anhalt, and Thüringen.

${ }^{9}$ The reporting requirements are set by the Foreign Trade and Payments Regulation. Reporting thresholds have been changed in the past, for details and a documentation on 
direct participating interests are to be reported whenever nonresidents hold more than $50 \%$ in a domestic firm and these dependent enterprises themselves hold $10 \%$ or more of the shares or voting rights in other domestic enterprises. An appealing feature of this data-set is that it comprises the universe of inward FDI (above the reporting threshold) undertaken in Germany. For each of these enterprises, we have information about the municipality where their German headquarters are located. ${ }^{10}$

Municipality-level data on the qualification of employees were compiled on special request based on the universe of German social-security records of the German Federal Labor Agency (Bundesagentur für Arbeit). The observations are the universe of workers registered for unemployment insurance, representing around $80 \%$ of the German workforce. ${ }^{11}$ Our skill measure is the share of workers with tertiary school education.

Municipality-level data on business tax rates, population, geographical area, the independency ratio, the fraction of land area covered with buildings and streets (a measure of available infrastructure), and gross investments are provided by different federal statistical offices of the 16 German states (Länder) in the database Statistik Lokal distributed by the German Statistical Office (Statistisches Bundesamt).

As mentioned before, there are two advantages of looking at location choices at the sub-national level. One is that firms face a much more homogeneous institutional setting across municipalities within a country than at the international level. Another advantage of using sub-national data is that one may account more accurately for the heterogeneity of locations. Crosscountry data use national averages that might suffer from aggregation bias. ${ }^{12}$

the micro-level data set $M i D i$ see Lipponer (2008).

${ }^{10}$ In fact, the information contained in the data-set does not identify individual subsidiaries but refers to regional headquarters which may report data on several of their subsidiaries. These headquarters may be responsible for a production facility at the same location or a set of subsidiaries in Germany. This is not of importance here, since we focus on regional headquarters location and the number of such entities (rather than employees, turnover, etc.; the latter would be impossible to assign to headquarters versus subsidiaries).

${ }^{11}$ Coverage includes full- and part-time workers of private enterprises, apprentices, and other trainees, as well as temporarily suspended employment relationships. Civil servants, student workers, and self-employed individuals are excluded and make up the remaining $20 \%$ of the formal-sector labor force.

${ }^{12}$ Consider two countries A and B with identical national averages. For instance, country A might have a skilled labor force but a bad infrastructure in one half of the country 
By looking at the smallest regional unit (municipalities), aggregation bias is ruled out.

German municipalities have autonomy in determining the local business tax rate, while the tax base is defined by the federal tax law which applies uniformly in all municipalities. ${ }^{13}$ Profit-shifting between plants in an attempt to escape the local business tax is avoided by formula apportionment: firm profits to be taxed are apportioned to each municipality according to the share of payroll paid there. ${ }^{14}$ We expect headquarters to represent an important share of total payroll, so that the local business tax rate is an important determinant in the location decision of headquarters.

In Germany, there are over 12,000 municipalities. For 11,094 of these, we have a panel data set of the dependent and explanatory variables over the period 2001 to 2005 with at least two consecutive observations in the sample period. For the cross-section in year 2005, we have data on 11,208 municipalities. ${ }^{15}$ Table 1 shows descriptive statistics of the municipal data for 2005. In that year, only 1,674 municipalities - or 14\% - hosted foreign MNE headquarters.

Figure 1 shows a histogram of the number of MNE headquarters across all municipalities in 2005. Whereas $86 \%$ of the municipalities did not host a single MNE headquarters, six municipalities (Hamburg, Munich, Frankfurt, Düsseldorf, Berlin and Cologne) hosted more than 200 each. Altogether, the latter six municipalities hosted almost one third of all foreign headquarters in Germany in that year. Figure 2 illustrates the geographical distribution of MNE headquarters.

and a good infrastructure but unskilled labor in the other half of the country. Country $\mathrm{B}$, in contrast, might have both skilled labor and a good infrastructure in one half of the country and neither skilled labor nor a good infrastructure in the other half of the country. These sub-national differences might matter for aggregate outcomes, but are washed out in national aggregates.

${ }^{13}$ There have been reforms about business tax law across the years. However, no such change has been undertaken in the period we consider here (2001-2005).

${ }^{14}$ See the German business tax law, in particular, §29 GewStG (Gewerbesteuergesetz).

${ }^{15}$ The difference between the total number of more than 12,000 municipalities and the smaller ones in the panel and cross-section accrues to lacking data on some of the explanatory variables for municipalities in the state of Mecklenburg-Vorpommern (except for the seven Kreisfreie Städte - i.e., larger cities - in that state: Greifswald, Neubrandenburg, Rostock, Schwerin, Stralsund, and Wismar). 
- Figures 1 and $2-$

Let us first consider the simple correlation between the presence of local MNE headquarters and the business tax rate in German municipalities unconditional on other determinants of location. For this, let us use the crosssectional data of 2005 and illustrate the relationship between the number of MNE headquarters and the business tax rate in simple scatter plots.

- Figures $3 \mathrm{a}$ and $3 \mathrm{~b}-$

In Figure 3a, we consider the relationship for all municipalities. In Figure 3b, we illustrate it only for municipalities with a positive number of headquarters. Obviously, irrespective of which of the two figures we look at, the unconditional relationship is positive. Do municipalities with higher business tax rates attract a larger number of foreign headquarters? This sounds counter-intuitive. However, conditional on other factors - such as the availability of skilled workers, region size, a relatively large fraction of population in working-age, etc. - high business tax rates may well be harmful for headquarters location irrespective of the unconditional relationship in Figures $3 \mathrm{a}$ and 3b. We may refer to the source of the positive relationship between the number of foreign MNE headquarters and the local business tax rate in Figures $3 \mathrm{a}$ and $3 \mathrm{~b}$ as one of endogeneity of business tax rates - i.e., their correlation with observable or unobservable determinants of the number of MNE headquarters in a municipality. To shed light on the causal effect of business tax rates, we now turn to multivariate negative binomial and Poisson model regressions.

\section{Econometric issues}

According to the descriptive statistics, the number of foreign MNE headquarters in Germany, our dependent variable, is a count which takes the value zero in many municipalities. Hence, the distribution function of the dependent variable places probability mass at nonnegative values only. Moreover, the density function is skewed to the left, and the data are concentrated on a few small discrete values and intrinsically heteroskedastic with variance increasing in the mean. This nature of the data likely leads to inconsistent and certainly to inefficient parameter estimates in linear regression models. 
However, such problems can be avoided by means of econometric models for count data.

The most frequently applied count data model is the Poisson regression model. ${ }^{16}$ It is obtained by assuming that each realization of the count dependent variable $y_{i}$ for cross-sectional observation $i$ (in our case, $y_{i}$ would be the number of headquarters hosted by municipality $i$ ) is drawn from a Poisson distribution with parameter $\lambda\left(x_{i} ; \beta\right)=\exp \left(x_{i}^{\prime} \beta\right)$, where $x_{i}^{\prime}$ is a $1 \times K$ vector of explanatory variables and $\beta$ a $K \times 1$ parameter vector to be estimated. The conditional probability distribution of the count variable is given by

$$
f\left(y_{i}\right)=\frac{\exp \left(-\exp \left(x_{i}^{\prime} \beta\right)\right) \exp \left(y_{i} x_{i}^{\prime} \beta\right)}{y_{i} !}
$$

and the conditional mean and variance are simultaneously determined by the parameter $\lambda\left(x_{i} ; \beta\right)$ :

$$
E\left(y_{i} \mid x_{i}^{\prime}\right)=\operatorname{Var}\left(y_{i} \mid x_{i}^{\prime}\right)=\exp \left(x_{i}^{\prime} \beta\right) .
$$

This last feature of the Poisson distribution (referred to as equidispersion, or equality of mean and variance) renders the Poisson regression model often too restrictive in applications. In particular, the model tends to under-predict the frequency of zeros and of large counts for data in which the actual variance is larger than the mean (referred to as over-dispersion). In our application, we have both a large number of zeros and a few very large counts so that overdispersion is likely a problem. As Figure 1 shows, the tail of the distribution is very long with $86 \%$ of the municipalities hosting no multinational but one municipality hosting 615 multinationals in 2005.

An approach which is more flexible than the Poisson regression model is the negative binomial model (NB), which allows for unobserved heterogeneity by treating the parameter $\lambda$ of the Poisson process as a random variable. This model is obtained by setting $\lambda_{i}=\mu_{i} \nu_{i}$, where $\mu_{i}=\exp \left(x_{i}^{\prime} \beta\right)$, and the random component $\nu_{i}>0$ is gamma-distributed with $E\left(\nu_{i}\right)=1$ and $\operatorname{Var}\left(\nu_{i}\right)=\alpha$. The conditional mean and variance of the NB model are ${ }^{17}$

$$
\begin{aligned}
E\left(y_{i} \mid x_{i}^{\prime}\right) & =\mu_{i} \\
\operatorname{Var}\left(y_{i} \mid x_{i}^{\prime}\right) & =\mu_{i}\left(1+\alpha \mu_{i}\right)
\end{aligned}
$$

\footnotetext{
${ }^{16}$ For a thorough discussion of the count data models discussed in this section, see Winkelmann (2003) and Cameron and Trivedi (2006).

${ }^{17}$ The model with this particular parametrization is known as NB type-II model (see Cameron and Trivedi, 2006).
} 
thus allowing for over-dispersion and providing a good fit to many types of data.

For data like ours, with $86 \%$ of zero observations, zero-inflated (ZI) models - which assume an extra proportion of zeros additionally to the zero observations arising from the count data distribution - should fit the data even better. Zeros are allowed to occur as an outcome of two different regimes. In one regime the outcome will always be zero and in the other one the standard count process is at work resulting in either zero or positive values. The model combines a binary variable describing the probability of extra zeros with a standard count variable. The probability function is given by

$$
f\left(y_{i}\right)= \begin{cases}\omega_{i}+\left(1-\omega_{i}\right) g\left(y_{i}=0\right) & \text { if } y=0, \\ \left(1-\omega_{i}\right) g\left(y_{i} \mid y_{i}>0\right) & \text { if } y \geq 1,\end{cases}
$$

where $\omega_{i}$ can be a logit and $g\left(y_{i}\right)$ a Poisson or an NB density. All such models (including Poisson, NB, and ZI versions thereof) can be estimated by the maximum likelihood method. In our application, the binary process reflects the economic suitability of a municipality for hosting a multinational headquarters at all, and the conditional mean of the count process describes the number of MNE headquarters that are actually attracted given a municipality's general suitability for headquarters location.

Eventually, one might be worried about business tax rates being endogenous. For instance, this would be the case if the average municipality altered business tax rates to attract foreign headquarters in particular. ${ }^{18}$ Mullahy (1997) derives moment conditions for generalized method of moments (GMM) estimation of count data models with endogenous regressors and valid instruments. Consider the Poisson regression model with a multiplicative error term

$$
y_{i}=\exp \left(x_{i}^{\prime} \beta\right) \eta_{i} .
$$

The following moment restriction follows from the first-order condition of the

\footnotetext{
${ }^{18}$ Notice that this is more than to say that municipalities used business tax rates to attract firms in general. In our application, the average municipality is not able to attract any foreign headquarters. This may be seen as an indication that the attraction of foreign headquarters is not the most important policy objective of the average German municipality. Hence, we expect the endogeneity issue as a subordinate one, here. However, we mention and apply suitable methods for completeness and as a robustness check to the conventional count data models.
} 
Poisson regression model: ${ }^{19}$

$$
E\left[y_{i}-\exp \left(x_{i}^{\prime} \beta\right) \mid x_{i}^{\prime}\right]=E\left[\exp \left(x_{i}^{\prime} \beta\right)\left(\eta_{i}-1\right) \mid x_{i}^{\prime}\right]=0 .
$$

This condition holds as long as $\eta_{i}$ is uncorrelated with the regressors $x_{i}^{\prime}$ and $E\left(\eta_{i} \mid x_{i}^{\prime}\right)=1 .{ }^{20}$ Mullahy considers the case where $E\left(\eta_{i} \mid x_{i}^{\prime}\right) \neq 1$ and a vector of instruments $z_{i}^{\prime}$ of dimension $1 \times P$ with $P \geq K$ is available such that $E\left(\eta_{i} \mid z_{i}^{\prime}\right)=1$. Then, the moment conditions

$$
E\left[\exp \left(-x_{i}^{\prime} \beta\right) y_{i}-1 \mid z_{i}^{\prime}\right]=0
$$

can be used to consistently estimate the parameter vector $\beta$. We use Mullahy's approach with cross-sectional data under the assumption of endogenous tax rates.

An alternative approach of addressing the problem of endogeneity arises with panel data. Windmeijer (2006) discusses moment conditions that can be used to estimate the parameter vector consistently allowing for correlation between the individual effects and the regressors under different assumptions about the exogeneity of the explanatory variables.

Define

$$
\begin{aligned}
y_{i t} & =\exp \left(x_{i t}^{\prime} \beta\right) \exp \left(\eta_{i}\right) w_{i t} \\
& =\mu_{i t} \nu_{i} w_{i t}
\end{aligned}
$$

where $i$ is an index for municipalities, and $t=1, \ldots T$ is an index for time with $T$ with denoting the maximum number of years of a municipality-specific time series in the data. $\eta_{i}$ is a time-invariant, unobservable, municipality-specific component and $w_{i t}$ is a time-variant disturbance term. Notice that $\nu_{i}$ and $w_{i t}$ are scaling factors for the municipality-specific mean. With the panel data models, we allow that that $E\left(x_{i t} w_{i t-\tau}\right) \neq 0$ for $\tau \geq 0$, maintaining that $E\left(w_{i t} \nu_{i}\right)=0, E\left(w_{i t}\right)=1$ (both of them for $\left.t=1, \ldots, T\right)$ and $E\left(w_{i s} w_{i t}\right)=0$ (for any $s \neq t$ ).

We apply Chamberlain's (1992) quasi-differencing transformation to eliminate the multiplicative fixed effect $\nu_{i}$. The quasi-differencing approach is based on the following equation (see Windmeijer, 2006):

$$
s_{i t}=y_{i t} \frac{\mu_{i t-1}}{\mu_{i t}}-y_{i t-1}=\mu_{i t-1} \nu_{i}\left(w_{i t}-w_{i t-1}\right)
$$

\footnotetext{
${ }^{19}$ The Poisson maximum likelihood estimator solves the first-order conditions $\sum_{i=1}^{n}\left[y_{i}-\exp \left(x_{i}^{\prime} \beta\right)\right] x_{i}^{\prime}=0$.

${ }^{20}$ Whenever a constant term is included in $x_{i}^{\prime}$, then $E\left(\eta_{i}\right)=1$ can be assumed without loss of generality (see Mullahy, 1997).
} 
with moment conditions

$$
E\left(s_{i t} \mid z_{i t-1}\right)=E\left(\mu_{i t-1} \nu_{i} E\left(\left(w_{i t}-w_{i t-1}\right) \mid \nu_{i}, z_{i t-1}\right) \mid z_{i t-1}\right)=0,
$$

where $z_{i t-1}$ is a $1 \times P$ vector of instruments.

In our empirical analysis, we primarily adopt the assumption that business tax rates are exogenous to foreign headquarters location. Moreover, we mainly exploit variation contained in the cross-section, since the time series is short for which information about the municipality-level variables is available for all cross-sectional units (ranging from 2001 to 2005 at most). Over a short time-span, it is difficult to discern effects of explanatory variables with small time series variation from fixed municipality effects. However, we apply the above instrumental variable techniques with cross-sectional and panel data to shed light on the robustness - in qualitative terms - of the cross-sectional business tax effect on foreign MNE headquarters location.

\section{$5 \quad$ Empirical analysis}

We start by estimating models on the cross-sectional data-set and assume that the $N \times K$ matrix of explanatory variables includes - apart from $T A X$ (the log of the business tax rate) - the following variables: SKILL (the log share of employees with a tertiary education), POPDEN (the log population density), $A R E A$ (the log total area of the municipality in square kilometers), IDEPRAT (the log independency ratio, defined as the population aged 1564 divided by the total population), BUILT (the log fraction of area in a municipality which is covered by buildings and streets), INV (the log share of investment expenditures of the municipality in total expenditures), and EAST (a dummy for municipalities located in the New Länder, i.e., in the former Eastern German part of the country). Table 2 gives summary statistics for the covariates included in the analysis. ${ }^{21}$

In the cross-sectional models, we use two alternative dependent variables. One measure is the stock of MNEs in a municipality as of 2005 (labeled $M N E$ ) and the other one the number of new headquarters in 2005 $(N E W M N E)$. The latter may help avoiding a bias of the model parameters arising from the possible correlation between the tax rate of a municipality in

\footnotetext{
${ }^{21}$ The statistics correspond to the pooled observations over the period 2001-2005. The statistics for the cross section of 2005 are virtually identical.
} 
a given year and the number of MNEs located in the municipality in previous years. $^{22}$ Of course, $N E W M N E$ has a much larger number of zero entries than $M N E$, so using NB or ZI-type models as compared to simple Poisson regressions is even more important with $N E W M N E$. We generally use once-lagged values of the explanatory variables in the econometric models. Hence, we employ values for 2004 on the right-hand side of all cross-sectional models. This is to avoid any bias associated with contemporaneous shocks in the dependent and the explanatory variables. Since all explanatory variables except for $E A S T$ are in logs, the associated parameters can be interpreted as elasticities. Table 3 summarizes a set of benchmark regression results.

- Table 3 -

The numbers in Table 3 indicate that the over-dispersion parameter is significantly different from zero. Hence, the negative binomial model is better suited for the data and specification at hand than the Poisson model (see Winkelmann, 2003; and Cameron and Trivedi, 2006). With the fairly large fraction of zeros in the dependent variable, a separate modeling of the zero threshold is recommended. However, the parameter estimates are fairly stable qualitatively across the estimated models. Especially, when comparing the estimates of the negative binomial model with its zero-inflated counterpart in Table 3. There, even the 95\% confidence intervals around the coefficients are overlapping for most of the parameters (except for constant, $P O P D E N$, and AREA).

The key parameter of interest here is the one of $T A X$. It turns out that controlling for the suggested determinants of MNE headquarters location eliminates (most of) the bias obviously present in the unconditional relationship between $M N E$ and $T A X$ portrayed in Figures $3 \mathrm{a}$ and $3 \mathrm{~b}$. In Table 3, the estimated parameter is unambiguously negative and statistically significantly different from zero at the one percent level in all models employing $M N E$ as the dependent variable, and also with the NB model for $N E W M N E$. The parameter of $T A X$ is significantly different from zero at $10 \%$ with the zero-inflated negative binomial (ZINB) regression for $N E W M N E$.

Note that the effect of $T A X$ on the expected number of headquarters in a municipality is of considerable magnitude. As mentioned before, the coefficients should be interpreted as elasticities: a one-percent decline in

\footnotetext{
${ }^{22}$ We present and discuss estimates based on instrumental variable regressions and panel data models below.
} 
$T A X$ is related to an increase in the expected number of headquarters of between $150 \%$ and $450 \%$ percent. However, recall that many municipalities do not attract foreign headquarters at all. So, it is useful to compute the marginal effect of $T A X$ evaluated at the sample mean. ${ }^{23}$ We find that, for the average municipality, a one-percent reduction of the municipal tax rate - which is equivalent to a decline by about 0.14 percentage points - leads to an increase in the number of headquarters of foreign MNEs by about 0.05 in the (preferred) ZINB model for $N E W M N E$ in Table 3.

A higher fraction of skilled workers in a municipality raises the number of MNE headquarters as predicted, e.g., by the knowledge-capital model of the multinational enterprise (Carr, Markusen, and Maskus, 2001; Markusen, 2002; Markusen and Maskus, 2002). Larger regions attract more headquarters as predicted by a variety of models of MNEs (see Markusen, 2002; and Barba Navaretti and Venables, 2004). This is reflected in the positive coefficients for population density $(P O P D E N)$ and geographical area (AREA). Region size should not only matter in terms of geographical area or the number of potential consumers but also with regard to the size of the available work force. Hence, not surprisingly, we find that MNEs tend to locate in those regions where the fraction of the population of working age (IDEPRAT) is large.

The coefficient of the relative size of the area covered with buildings and streets $(B U I L T)$ suggests that such space is particularly important for MNE location. After controlling for the latter, the share of investments in a municipality's total expenditures $(I N V)$ seems to be of minor importance for MNE headquarters location. Finally, as expected, foreign MNEs are less inclined to locate their headquarters in the New (formerly Eastern German) Länder.

\subsection{Instrumental variables estimation}

The results in Table 3 indicate that conditioning on the included covariates eliminates a large part of the bias of the $T A X$ parameter contaminating an

\footnotetext{
${ }^{23}$ In nonlinear models the partial effect of a variable on the conditional mean of the dependent variable is a function of the other regressors and parameter estimates as well, and needs to be evaluated at some value of the covariates. In applied research, it is common to evaluate marginal effects at the first moment of the distribution of the covariates, i.e., at the sample mean. See the Appendix for the derivation of the marginal effects and their standard errors for the models estimated in Table 3.
} 
unconditional relationship between $T A X$ and $M N E$. However, there may be some endogeneity left, and this could be particularly important in the crosssectional models employing $M N E$ rather than $N E W M N E$. For instance, such a bias would arise from tax competition between municipalities in order to attract foreign MNE headquarters. The source of the bias would be a correlation of the explanatory variables with any possible omitted regressors, time-variant or time-invariant.

The first problem can be overcome by means of instrumental variable count data model regression and the second one by quasi-differenced count data model estimation using panel data. The corresponding models are summarized in Table 4. In one of the models, we use the stock of MNE headquarters per municipality $(M N E)$ in 2005 with cross-sectional instrumental variable GMM estimation (IV-GMM). With appropriate instruments, IVGMM may overcome the bias associated with the omission of time-variant or time-invariant variables from the model. Alternatively, we employ panel data and quasi-differenced GMM estimation. ${ }^{24}$

Theoretical work on spatial tax competition suggests that a jurisdiction's tax rate is a function of both local and other jurisdictions' characteristics. Strategic interaction among jurisdictions suggests that jurisdictions set their tax rate in response to the one(s) applied in neighboring jurisdictions. In equilibrium, tax rates in all jurisdictions are determined by economic fundamentals (such as region size, factor endowments, etc.). Accordingly, a large fraction of empirical work addresses the problem of tax competition by means of instrumental variables regressions where weighted tax rates of other municipalities are modeled as a function of weighted economic fundamentals there (see Brett and Pinkse, 2000; Egger, Pfaffermayr, and Winner, 2005a,b). In a reduced form, local tax rates are a function of economic fundamentals of the local jurisdiction and weighted tax rates of the "neighbors". We use the latter idea to instrument municipality-level tax rates with average characteristics of neighboring municipalities. In the cross section, the instruments used are the averages of the share of area covered with buildings and streets,

\footnotetext{
${ }^{24}$ Neither for IV-GMM nor for quasi-differenced GMM did the estimation procedure converge when using $N E W M N E$ instead of $M N E$ as the dependent variable. The reason for this is to be seen in the extremely large number of zeros in $N E W M N E$ in any considered year.
} 
the total area, and the share of agricultural area (all in logs) for (i) all municipalities within a radius of 0 and 25 kilometers from the center of a given municipality and for (ii) all municipalities within a radius of 25 and $50 \mathrm{~km}$ from the center of a given municipality. In the panel estimation we use the averages of the share of area covered with buildings and streets, the share of agricultural area, the independency ratio, and the skilled labor share for all neighboring municipalities within a $50 \mathrm{~km}$ radius. ${ }^{25}$

The first column summarizes the findings based on an instrumental variable count data model for the cross-sectional data-set of 2005. Results are based on the GMM routine described in Section $4 .{ }^{26}$ The instruments are relevant and pass the over-identification test. The parameters of TAX, SKILL and POPDEN as well as the variables BUILT and $A R E A$ exhibit the same sign as in Table 3 and are statistically significant. The remaining variables turn out to be insignificant under IV-GMM. As expected, the parameter estimate of $T A X$ is negative and higher in absolute value than in the benchmark models in Table 3. If some remaining endogeneity were to bias the coefficients in Table 3 downwards in absolute value (i.e. towards the unconditional relationship in Figures $3 \mathrm{a}$ and $3 \mathrm{~b}$ ), we would expect an instrumental variables model to raise the point estimate as compared to the models in Table 3. If the origin of the bias was mainly due to the omission of relevant time-invariant variables, we would expect the bias in Table 3 to be larger when using the stock of MNE headquarters $(M N E)$ rather than new headquarters $(N E W M N E)$ as the dependent variable. Indeed, it turns out

\footnotetext{
${ }^{25}$ All instruments are measured in logs. Notice that the list of instruments is slightly different between the cross-sectional and the panel data models. The reason is that we may only exploit information from time-variant instruments in the panel model. For instance, $A R E A$ and $E A S T$ do not vary across the years and can not be used as instruments in the panel data models. With panel data, we use a municipality's share of area devoted to agriculture instead of $A R E A$. This variable exhibits some time variation and is orthogonal enough to BUILT over time to include it separately (by way of contrast, the two variables are highly correlated cross-sectionally and should not be included in the models together in Table 3 to avoid efficiency losses associated with irrelevant instruments). Moreover, weighted characteristics within a radius of 25 kilometers are strongly correlated over time with the ones within a radius of 50 kilometers over time. So we exclude the former and only use the latter in the panel models.

${ }^{26}$ Notice that the econometric model requires the endogenous variable to be unlimited in its value range. Obviously, this is not the case for $T A X$. Using logistically transformed business tax rates $(T A X L O G=\ln ([\operatorname{tax}$ rate $] /[1-\operatorname{tax}$ rate $]))$ ensures that the endogenous variable $(T A X L O G)$ is unlimited. However, it turns out that the results are very similar in a model which employs $T A X$ instead of $T A X L O G$.
} 
that the instrumental variables model leads to a parameter estimate of $T A X$ which is closer to the $N E W M N E$-based estimates in Table 3 than to the $M N E$-based ones. The difference between the parameter for $T A X$ in the ZINB model of Table 3 and the IV-GMM model in Table 4 is not statistically significant at commonly used levels of significance.

The second column in Table 4 reports estimates based on the quasidifferenced GMM estimator derived in Windmeijer (2006). We use the instruments as described before and in the table footnote. However, we eliminate the time-invariant variables $E A S T$ and $A R E A$ from this regression. It turns out that the parameter of $T A X$ is significantly different from zero and exhibits the same sign as in the benchmark regressions of Table 3 . The estimated elasticity of the number of MNEs with respect to $T A X$ is much bigger than before. However, the confidence interval is larger, too. ${ }^{27}$ So, we take the results from the quasi-differences GMM estimator mainly as in indication that the qualitative findings about a significant negative effect of higher business tax rates on the location of foreign MNE headquarters in Germany are robust.

Overall, our findings suggest that a marginal reduction of business tax rates in the average municipality is not enough to attract foreign MNE headquarters. Municipality size and the availability of workers, especially skilled workers, are important. Only those municipalities which have a sufficiently attractive environment to be on the map of foreign MNEs when planning to locate subsidiaries in Germany will be able to attract foreign headquarters by reasonable reductions in their tax rates. Municipalities with less favorable environments would have to trade these off with sizable reductions in the business tax rate. For instance, the estimates in Table 3 imply that a one-percent reduction in business tax rates increases the number of foreign MNE headquarters in a region by about 0.05 . Hence, the preferred model indicates that the average municipality has to reduce its tax rate by about $20 \%$ (or 2.8 percentage points) to attract a single foreign headquarters. The average municipality may not want to do so, since the associated losses in tax income from national firms may easily outweigh the expected raise of tax

${ }^{27}$ As mentioned before, we do not see the panel model results as the most reliable ones. The reason is that there is little variation in tax rates and numbers of headquarters per municipality on average over the short time span covered by the data. To be more specific, 4,080 municipalities changed their tax rate at least once during that time span but in only 345 of those did the number of MNE headquarters actually change (increase or decline). Hence, the $T A X$ parameter is identified from a fairly small fraction of observations. 
income collected from the foreign MNE.

In comparison to work at the aggregated (country-pair) level, the estimated business tax elasticities on foreign investments are very high (see de Mooij and Ederveen, 2003, 2006, 2009, for an overview). However, it is well documented that elasticities estimated from sub-national data are higher than those obtained at the aggregate level (see Slemrod, 1990; Hines, 1996, for examples and de Mooij and Ederveen, 2003, for pointing to this fact). One fundamental difference between most of the work on profit taxes on foreign direct investment and ours is that we focus entirely on the extensive margin in terms of numbers of regional MNE headquarters. Work on the tax responsiveness of foreign direct investment at the aggregate (country or country-pair) level in general tends to mix effects on the extensive margin (i.e., on lumpy investment) and the intensive margin. And, finally, even though the elasticities are high, the average German municipality needs to change its business tax rate quite dramatically to become attractive to foreign investors at all.

\section{Concluding remarks}

This paper provides evidence on the impact of profit taxation for the location of regional headquarters of foreign MNEs using data for more than 11,000 German municipalities. We link data on local public finance and other municipality characteristics available from the German Statistical Office and the Federal Employment Agency with firm-level data from the German Central Bank about inbound foreign direct investments in Germany for the years 2001-2005.

One advantage of this data-set is that institutional characteristics and the taxation of other factors are much more homogeneous across municipalities within a country than in cross-country studies. Moreover, the number of municipalities foreign MNEs may locate in is larger by more than one order of magnitude than the number of countries for which profit taxes are typically available. So, the impact of profit taxes on MNE headquarters location may be identified much more precisely than in an international context.

Overall, we find that the business tax rate levied by a municipality negatively affects the number of MNEs it can attract. This impact is found after controlling for other important determinants of a foreign MNE's location decision. Irrespective of whether we assume that business tax rates are en- 
dogenous or not, the impact of business tax rates is of reasonable magnitude. The average German municipality was not able to attract any foreign headquarters at all over the years covered by our data. Such a municipality would have to lower its business tax rate by about twenty percent (or 2.8 percentage points) to lure a foreign MNE into its jurisdiction, according to our results. It is very likely that the associated gains in taxes collected from the foreign MNE would be lower than the losses the average municipality encountered from foregone business tax revenues collected from national enterprises.

Obviously, most municipalities do not find this attractive, since foreign capital is not the only important tax base to consider. However, larger municipalities with an abundant workforce, especially of skilled workers, may attract foreign MNE headquarters by much smaller changes in their tax rates. Implicitly, these results suggest that municipalities with generally favorable environments for firm location should be able to use their tax rates more successfully to attract foreign MNEs than those with less favorable environments. 


\section{References}

Baldwin, R., And P. R. Krugman (2004): "Agglomeration, integration and tax harmonisation," European Economic Review, 48(1), 1-23.

Barba Navaretti, G., And A. J. Venables (2004): Multinational firms in the world economy. Princeton University Press, Princeton.

Blonigen, B. A., And R. B. Davies (2004): "The effects of bilateral tax treaties on U.S. FDI activity," International Tax and Public Finance, 11(5), 601-622.

Blonigen, B. A., R. B. Davies, And K. Head (2003): "Estimating the knowledge-capital model of the multinational enterprise: comment," American Economic Review, 93(3), 980-994.

Blundell, R., R. Griffith, and F. Windmeijer (2002): "Individual effects and dynamics in count data models," Journal of Econometrics, 108(1), 113-131.

Borck, R., ANd M. Pflüger (2006): "Agglomeration and tax competition," European Economic Review, 50(3), 647-668.

Brett, C., And J. Pinkse (2000): "The determinants of municipal tax rates in British Columbia," Canadian Journal of Economics, 33(3), 695-714.

Brühlhart, M., M. Jametti, And K. Schmidheiny (2007): "Do agglomeration economies reduce the sensitivity of firm location to tax differentials?, York University Economics Working Paper 2001-09.

Bucovetsky, S., And A. Haufler (2008): "Tax competition when firms choose their organizational form: should tax loopholes for multinationals be closed?," Journal of International Economics, 74(1), 188-201.

Cameron, C. A., And P. K. Trivedi (2006): Regression analysis of count data. Cambridge University Press, Cambridge.

Carr, D. L., J. R. Markusen, and K. E. Maskus (2001): "Estimating the knowledge-capital model of the multinational enterprise," American Economic Review, 91(3), 693-708.

Chamberlain, G. (1992): "Comment: sequential moment restrictions in panel data," Journal of Business \&3 Economic Statistics, 10(1), 20-26.

DAvies, R. B. (2003): "The OECD model tax treaty: tax competition and twoway capital flows," International Economic Review, 44(2), 725-753. 
(2005): "State tax competition for foreign direct investment: a winnable war?," Journal of International Economics, 67(2), 498-512.

DE MooiJ, R. A., AND S. Ederveen (2003): "Taxation and foreign direct investment: a synthesis of empirical research," International Tax and Public Finance, 10(6), 673-693.

(2006): "What a difference does it make? Understanding the empirical literature on taxation and international capital flows," EC European Economy - Economic Papers 261.

(2009): "Corporate tax elasticities: a readers guide to empirical findings," Oxford Review of Economic Policy, forthcoming.

Devereux, M., And R. Griffith (1998): "Taxes and the location of production: evidence from a panel of US multinationals," Journal of Public Economics, 68(3), 335-367.

Devereux, M., And R. G. Hubbard (2003): "Taxing multinationals," International Tax and Public Finance, 10(4), 469-487.

Egger, P. H., And J. H. Bergstrand (2007): "A knowledge-and-physicalcapital model of international trade, foreign direct investment, and foreign affiliate sales: developed countries," Journal of International Economics, 73(2), 278-308.

Egger, P. H., M. Pfaffermayr, S. Loretz, And H. Winner (2008): "Bilateral effective tax rates and foreign direct investment," International Tax and Public Finance, forthcoming.

Egger, P. H., M. Pfaffermayr, and H. Winner (2005a): "Commodity taxation in a 'linear' world: a spatial panel data approach," Regional Science and Urban Economics, 35(5), 527-541.

_ (2005b): "An unbalanced spatial panel data approach to US state tax competition," Economics Letters, 88(3), 329-335.

Grubert, H., AND J. Mutti (2004): "Empirical asymmetries in foreign direct investment and taxation," Journal of International Economics, 62(2), 337-358.

Haufler, A., and I. Wooton (1999): "Country size and tax competition for foreign direct investment," Journal of Public Economics, 71(1), 121-139. 
Head, C. K., And T. Mayer (2004): "Market potential and the location of Japanese investment in Europe," Review of Economics and Statistics, 86(4), 959-972.

Hines JR., J. R. (1996): "Altered states: taxes and the location of foreign direct investment in America," American Economic Review, 86(5), 1076-1094.

Huizinga, H., And G. Nicodème (2006): "Foreign ownership and corporate income taxation: an empirical evaluation," European Economic Review, 50(5), $1223-1244$.

Huizinga, H., AND S. B. Nielsen (1997): "Capital income and profit taxation with foreign ownership of firms," Journal of International Economics, 42(1), 149-165.

JANEBA, E. (1995): "Corporate income tax competition, double taxation treaties, and foreign direct investment," Journal of Public Economics, 56(2), 311-325.

Lipponer, A. (2008): "Microdatabase direct investment - MiDi. A brief guide," Deutsche Bundesbank Technical Documentation, Frankfurt. Download: http://www.bundesbank.de/download/vfz/fdi/vfz_mikrodaten_guide.pdf.

List, J. A. (2001): "US county-level determinants of inbound FDI: evidence from a two-step modified count data model," International Journal of Industrial Organization, 19(6), 953-973.

Ludema, R., ANd I. Wooton (2000): "Economic geography and the fiscal effects of regional integration," Journal of International Economics, 52(2), 331-357.

Markusen, J. R. (2002): Multinational firms and the theory of international trade. MIT Press, Cambridge.

Markusen, J. R., And K. E. Maskus (2002): "Discriminating among alternative theories of the multinational enterprise," Review of International Economics, 10(4), 694-707.

Mullahy, J. (1997): "Instrumental variable estimation of Poisson regression models: applications to models of cigarette smoking behavior," Review of Economics and Statistics, 79(4), 586-593.

Overesch, M., AND G. WAmser (2008): "Who cares about corporate taxation? Asymmetric tax effects on outbound FDI," Ifo Working Paper No. 59, Munich. 
PAPKe, L. E. (1991): "Interstate business tax differentials and new firm location. Evidence from panel data," Journal of Public Economics, 45(1), 47-68.

RAFF, H. (2004): "Preferential trade agreements and tax competition for foreign direct investment," Journal of Public Economics, 88(12), 2745-2763.

Slemrod, J. (1990): "Tax effects on foreign direct investment in the United States: evidence from a cross-country comparison," in Taxation in the Global Economy, ed. by A. Razin, and J. Slemrod, pp. 79-117. Chicago University Press, Chicago.

Wilson, J. D. (1987): "Trade, capital mobility and tax competition," Journal of Political Economy, 95(4), 835-856.

304.

(1999): "Theories of tax competition," National Tax Journal, 52(2), 269-

Windmeijer, F. (2006): "GMM for panel count data models," Bristol Economics Discussion Papers 06/591, Department of Economics, University of Bristol, UK.

Winkelmann, R. (2003): Econometric analysis of count data. Springer, Heidelberg, 3rd edn.

Wooldridge, J. M. (1991): "Multiplicative panel data models without the strict exogeneity assumption," MIT Working Paper No. 574. 


\section{Appendix}

\section{Marginal effects in count data models}

The marginal effect of any explanatory variable $x_{i j}$ on the conditional mean of the dependent variable $y_{i}$ is given by

$$
\frac{\partial E\left(y_{i} \mid x_{i}\right)}{\partial x_{i j}}=\exp \left(x_{i}^{\prime} \beta\right) \beta_{j}=\gamma_{j}^{N B}
$$

for the negative binomial model and by

$$
\frac{\partial E\left(y_{i} \mid x_{i}\right)}{\partial x_{i j}}=\frac{\exp \left(x_{i}^{\prime} \beta\right)}{\left(1+\exp \left(x_{i}^{\prime} \beta\right)\right)^{2}} \beta_{j}=\gamma_{i}^{Z I N B}
$$

for the zero-inflated negative binomial model, in the case where the vector of explanatory variables $x_{i}^{\prime}$ is identical in the inflation model and the main equation. The marginal effects depend on the explanatory variables and need to be evaluated at some value. We evaluate them at the sample mean.

The standard errors of the marginal effects were computed according to the asymptotic variance formulas

$$
A s y . \operatorname{Var}[\hat{\gamma}]_{N B}=\left(\exp \left(\bar{x}^{\prime} \hat{\beta}\right)\right)^{2}\left[I_{k}+\exp \left(\bar{x}^{\prime} \hat{\beta}\right) \hat{\beta} \bar{x}^{\prime}\right] V\left[I_{k}+\exp \left(\bar{x}^{\prime} \hat{\beta}\right) \bar{x} \hat{\beta}^{\prime}\right]
$$

and

$$
A s y \cdot \operatorname{Var}[\hat{\gamma}]_{Z I N B}=[\Lambda(1-\Lambda)]^{2}\left[I_{k}+(1-2 \Lambda) \hat{\beta} \bar{x}^{\prime}\right] V\left[I_{k}+(1-2 \Lambda) \bar{x} \hat{\beta}^{\prime}\right]
$$

where $\bar{x}$ is the $K \times 1$ vector of sample means, $\hat{\beta}$ is the $K \times 1$ vector of parameter estimates, $I_{k}$ is an identity matrix of dimension $K, V$ is the $K \times K$ estimated asymptotic covariance matrix of $\hat{\beta}$ and $\Lambda=\exp \left(\bar{x}^{\prime} \hat{\beta}\right) /\left(1+\exp \left(\bar{x}^{\prime} \hat{\beta}\right)\right)$ is a scalar. 
Table 1: Descriptive statistics

\begin{tabular}{lrrrr}
\hline \hline Variable & Mean & Std. dev. & Min. & \multicolumn{1}{c}{ Max. } \\
\hline Business tax rate & 0.14 & 0.01 & 0.09 & 0.31 \\
General Expenditures & $16,198.13$ & 248,476 & 15.57 & $21,800,000$ \\
Investment Expenditure & $1,449.84$ & $9,160.54$ & 0 & 519,200 \\
Population & 7.03 & 45.45 & 0.005 & $3,395.18$ \\
Skilled labor share & 0.06 & 0.03 & 0.003 & 0.59 \\
Area covered with buildings and streets & 3.79 & 10.68 & 0.01 & 619.28 \\
Total area & 28.27 & 35.08 & 0.4 & 891.82 \\
\hline \hline
\end{tabular}

Note: Statistics refer to 11,208 German municipalities in 2005. Expenditures in 1,000 Euros. Population in 1,000. Area in $\mathrm{km}^{2}$. Sources: German Federal Labor Agency, Statistik Lokal, Ed. 2003-07, and Statistical offices of Berlin-Brandenburg, Bremen, Hamburg and Sachsen-Anhalt.

Table 2: Included covariates

\begin{tabular}{llrr}
\hline \hline Variable & \multicolumn{1}{c}{ Definition } & Mean & Std. dev. \\
\hline$T A X$ & $\ln$ (taxrate) & -1.96 & 0.10 \\
SKILL & $\ln$ (share of employees with tertiary education) & -2.92 & 0.46 \\
POPDEN & $\ln$ (total population / total area) & 0.01 & 1.01 \\
$A R E A$ & $\ln$ (total area) & 7.42 & 1.02 \\
$I D E P R A T$ & $\ln$ (population aged 15-65 / total population) & -0.40 & 0.05 \\
BUILT & $\ln$ (area covered with buildings and streets / total area) & -2.32 & 0.56 \\
$I N V$ & $\ln$ (investment expenditure / total expenditure) & -1.96 & 0.88 \\
$E A S T$ & Dummy for East Germany & 0.26 & 0.44 \\
\hline \hline
\end{tabular}

Note: Panel of 11,094 municipalities with at least two consecutive observations over the period 2001-2005. 
Table 3: Cross section 2005

\begin{tabular}{|c|c|c|c|c|}
\hline \multirow[b]{2}{*}{ Indep. variables } & \multicolumn{2}{|c|}{ Negative Binomial } & \multicolumn{2}{|c|}{ Zero-Inflated } \\
\hline & MNE & NEWMNE & MNE & NEWMNE \\
\hline \multirow[t]{2}{*}{$\overline{T A X}$} & $-2.514^{* * *}$ & $-2.594^{* * *}$ & $-1.571^{* * *}$ & $-4.578^{*}$ \\
\hline & $(0.332)$ & $(0.894)$ & $(0.448)$ & $(2.482)$ \\
\hline \multirow[t]{2}{*}{$S K I L L$} & $0.612^{* * *}$ & $1.296^{* * *}$ & $0.775^{* * *}$ & $1.016^{* * *}$ \\
\hline & $(0.069)$ & $(0.179)$ & $(0.084)$ & $(0.351)$ \\
\hline \multirow[t]{2}{*}{ POPDEN } & $1.115^{* * *}$ & $0.873^{* * *}$ & $0.621^{* * *}$ & 0.982 \\
\hline & $(0.099)$ & $(0.279)$ & $(0.122)$ & $(0.717)$ \\
\hline \multirow[t]{2}{*}{$A R E A$} & $1.198^{* * *}$ & $1.024^{* * *}$ & $0.797^{* * *}$ & $0.899^{* * *}$ \\
\hline & $(0.032)$ & $(0.079)$ & $(0.051)$ & $(0.256)$ \\
\hline \multirow[t]{2}{*}{ IDEPRAT } & $1.727^{* *}$ & 3.936 & 2.044 & $7.273^{*}$ \\
\hline & $(0.873)$ & $(2.73)$ & $(1.254)$ & $(3.759)$ \\
\hline \multirow[t]{2}{*}{$B U I L T$} & $0.762^{* * *}$ & $0.932 *$ & $0.732^{* * *}$ & 0.324 \\
\hline & $(0.167)$ & $(0.480)$ & $(0.189)$ & $(0.819)$ \\
\hline \multirow[t]{2}{*}{$I N V$} & -0.002 & 0.02 & -0.09 & 0.051 \\
\hline & $(0.042)$ & $(0.133)$ & $(0.055)$ & $(0.301)$ \\
\hline \multirow[t]{2}{*}{$E A S T$} & $-0.789 * * *$ & $-1.033^{* * *}$ & $-1.178^{* * *}$ & $-1.856^{* * *}$ \\
\hline & $(0.124)$ & $(0.327)$ & $(0.132)$ & $(0.521)$ \\
\hline \multirow[t]{2}{*}{ constant } & $-12.24^{* * *}$ & $-10.65^{* * *}$ & $-5.77^{* * *}$ & -12.84 \\
\hline & $(1.061)$ & $(2.723)$ & $(1.37)$ & $(8.04)$ \\
\hline \multirow[t]{2}{*}{$\alpha$} & 1.12 & 1.852 & 0.648 & 1.10 \\
\hline & $(0.079)$ & $(0.391)$ & $(0.087)$ & $(0.193)$ \\
\hline Wald test $\left(\chi^{2}\right)$ & 4909.2 & 1001.6 & 1328.43 & 125.7 \\
\hline $\mathrm{p}$-value & 0.000 & 0.000 & 0.000 & 0.000 \\
\hline Pseudo log-likelihood & -5676.71 & -932.82 & -5571.01 & -916.93 \\
\hline Observations & 11208 & 11208 & 11208 & 11208 \\
\hline Nonzero obs. & 1631 & 229 & 1631 & 229 \\
\hline $\begin{array}{l}\text { Marginal effect } \\
\text { of } T A X\end{array}$ & $\begin{array}{c}-0.17^{* * *} \\
(0.02)\end{array}$ & $\begin{array}{c}-0.008^{* * *} \\
(0.003)\end{array}$ & $\begin{array}{c}-0.22^{* * *} \\
(0.06)\end{array}$ & $\begin{array}{c}-0.05^{*} \\
(0.02)\end{array}$ \\
\hline
\end{tabular}

Notes: 1. Robust standard errors reported in parentheses.

2. All explanatory variables are in logs and lagged once (i.e. the values are for 2004).

3. The inflation model of the Zero-Inflated Negative Binomial model is a logit, the regressors are the same as in the main specification. Results available upon request.

4. Marginal effect evaluated at the sample mean. Standard errors in parentheses, for the derivation see appendix. *, **, and $* * *$ indicate significance at $10 \%, 5 \%$, and $1 \%$, respectively. 
Table 4: $T A X$ Instrumented: year 2005

Dependent variable:

$\mathrm{MNE}$

\begin{tabular}{|c|c|c|}
\hline $\begin{array}{l}\text { Indep. } \\
\text { variables }\end{array}$ & Cross section & $\begin{array}{c}\text { Panel, quasi- } \\
\text { differencing model }\end{array}$ \\
\hline$\overline{T A X}$ & $-5.34^{* *}$ & $-9.31^{* *}$ \\
\hline SKILL & $\begin{array}{c}(2.21) \\
0.46^{* * *} \\
(0.16)\end{array}$ & $\begin{array}{l}(4.66) \\
0.40 \\
(0.87)\end{array}$ \\
\hline POPDEN & $\begin{array}{c}0.66^{* * *} \\
(0.17)\end{array}$ & $\begin{array}{c}-4.08 \\
(5.98)\end{array}$ \\
\hline$A R E A$ & $\begin{array}{c}1.63^{* * * *} \\
(0.10)\end{array}$ & - \\
\hline IDEPRAT & $\begin{array}{l}0.32 \\
(2.67)\end{array}$ & $\begin{array}{c}-14.56 \\
(10.89)\end{array}$ \\
\hline$B U I L T$ & $\begin{array}{c}2.00^{* * *} \\
(0.29)\end{array}$ & $\begin{array}{l}6.31 \\
(5.93)\end{array}$ \\
\hline$I N V$ & $\begin{array}{l}0.05 \\
(0.15)\end{array}$ & $\begin{array}{c}-0.05 \\
(0.05)\end{array}$ \\
\hline$E A S T$ & $\begin{array}{c}-0.05 \\
(0.38)\end{array}$ & - \\
\hline constant & $\begin{array}{c}-19.36^{* * * *} \\
(4.82)\end{array}$ & - \\
\hline Sargan test & $\begin{array}{c}4.95 \\
5 \\
0.42\end{array}$ & $\begin{array}{c}1.47 \\
3 \\
0.68\end{array}$ \\
\hline $\begin{array}{lr}\text { Observations } & \\
& \mathrm{N} \\
\mathrm{NT}\end{array}$ & 10878 & $\begin{array}{l}11094 \\
39348\end{array}$ \\
\hline
\end{tabular}

Notes: 1. All explanatory variables in logs. For the cross-section explanatory variables are lagged once (i.e. the values are for 2004).

2. The cross section IV regression uses Mullahy's (1997) multiplicative moment conditions and the panel IV regression uses Chamberlain's (1992) transformation for the multiplicative error specification as detailed in the main text.

3. The instruments used in the cross section are the averages of the share of area covered with buildings and streets, the total area, and the share of agricultural area (all in logs) for (i) all municipalities within a radius of 0 and 25 kilometers from the center of a given municipality and for (ii) all municipalities within a radius of 25 and $50 \mathrm{~km}$ from the center of a given municipality. In the panel estimation we use the averages of the share of area covered with buildings and streets, the share of agricultural area, the independency ratio, and the skilled labor share for all neighboring municipalities within a $50 \mathrm{~km}$ radius.

4. One-Step results. Robust standard errors reported in parentheses. *, **, and *** indicate significance at $10 \%, 5 \%$, and $1 \%$, respectively. 
Figure 1: Histogram of number of foreign MNE headquarters in Germany

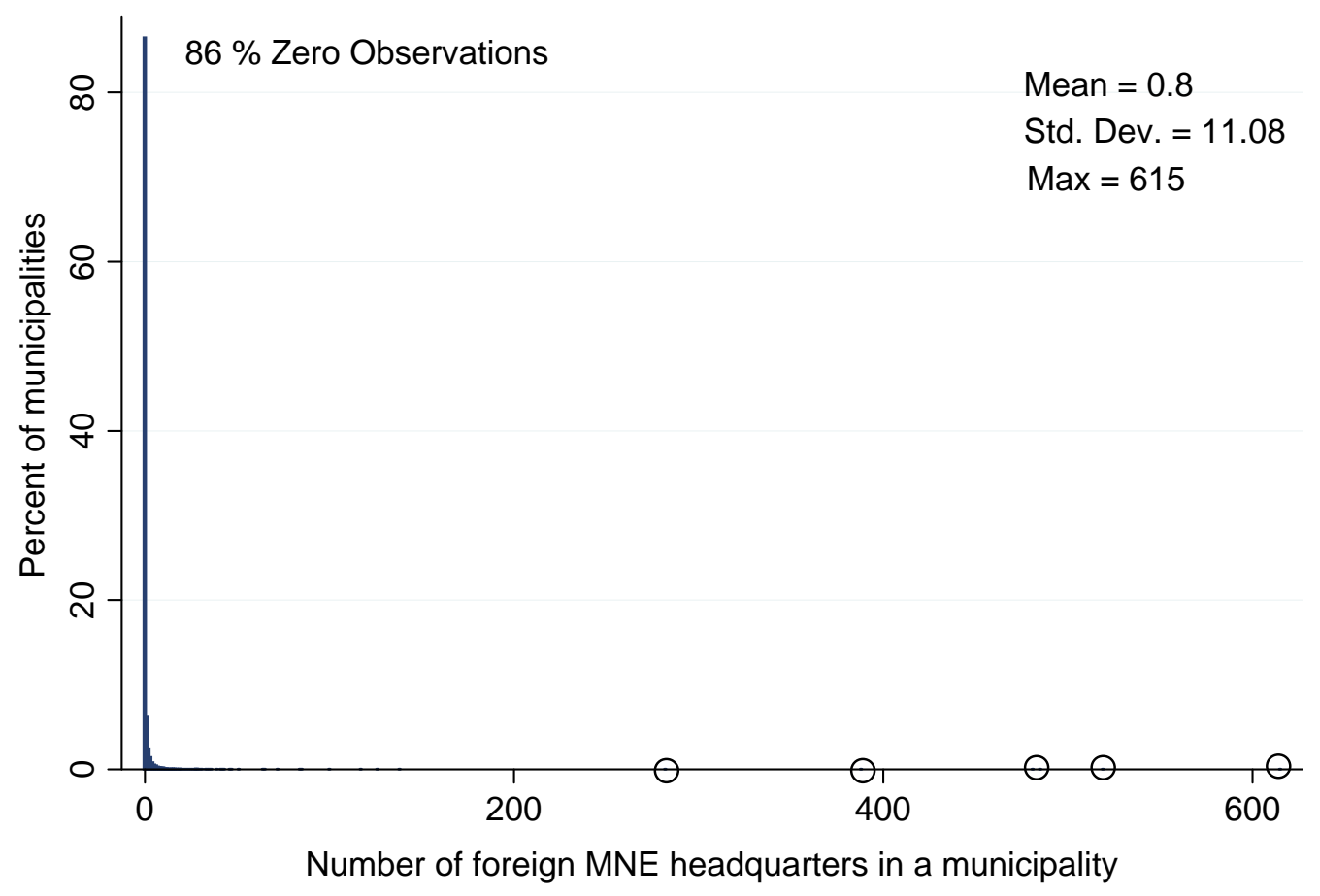




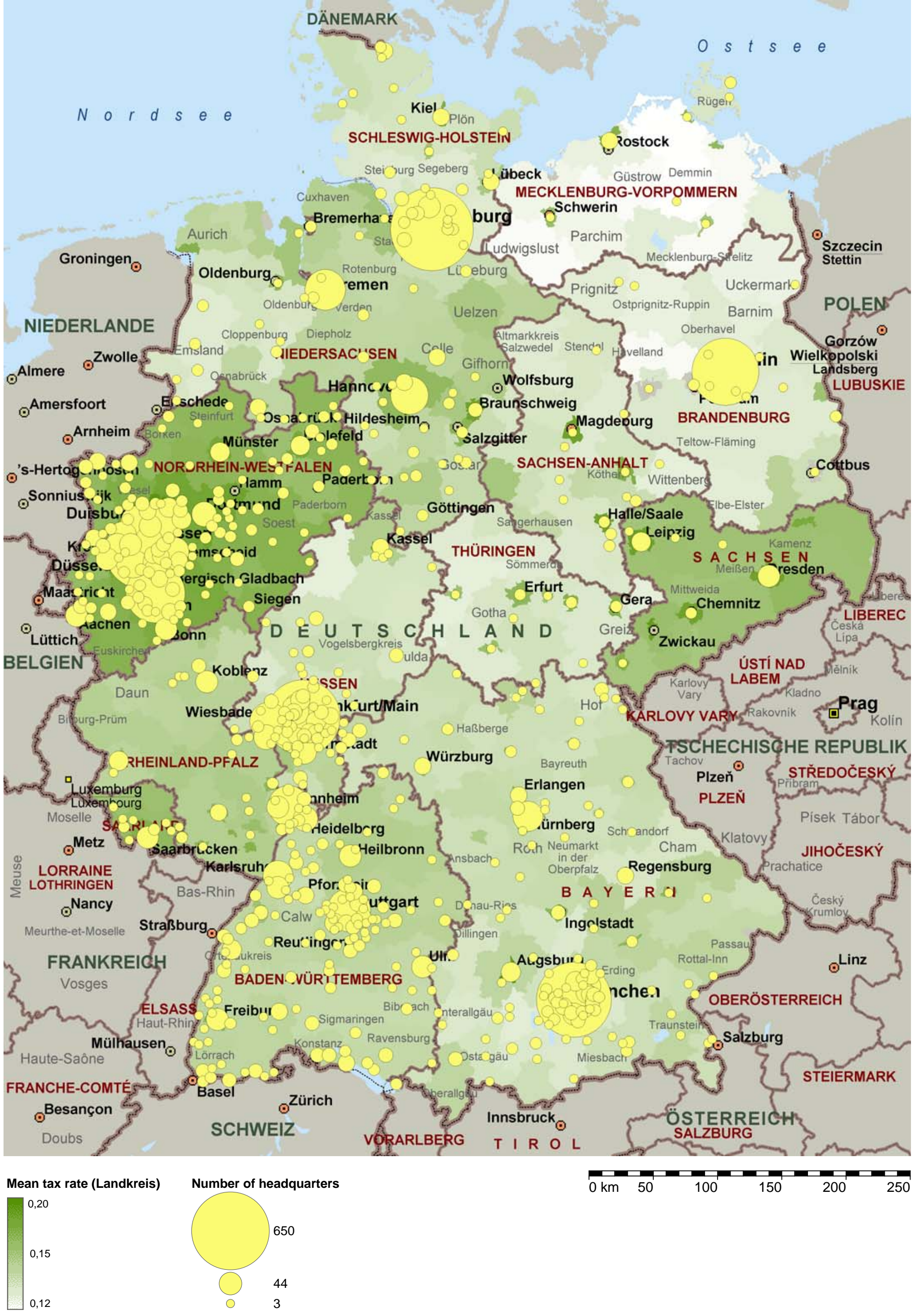


Figure 3a: Foreign MNE headquarters and the business tax rate Whole sample

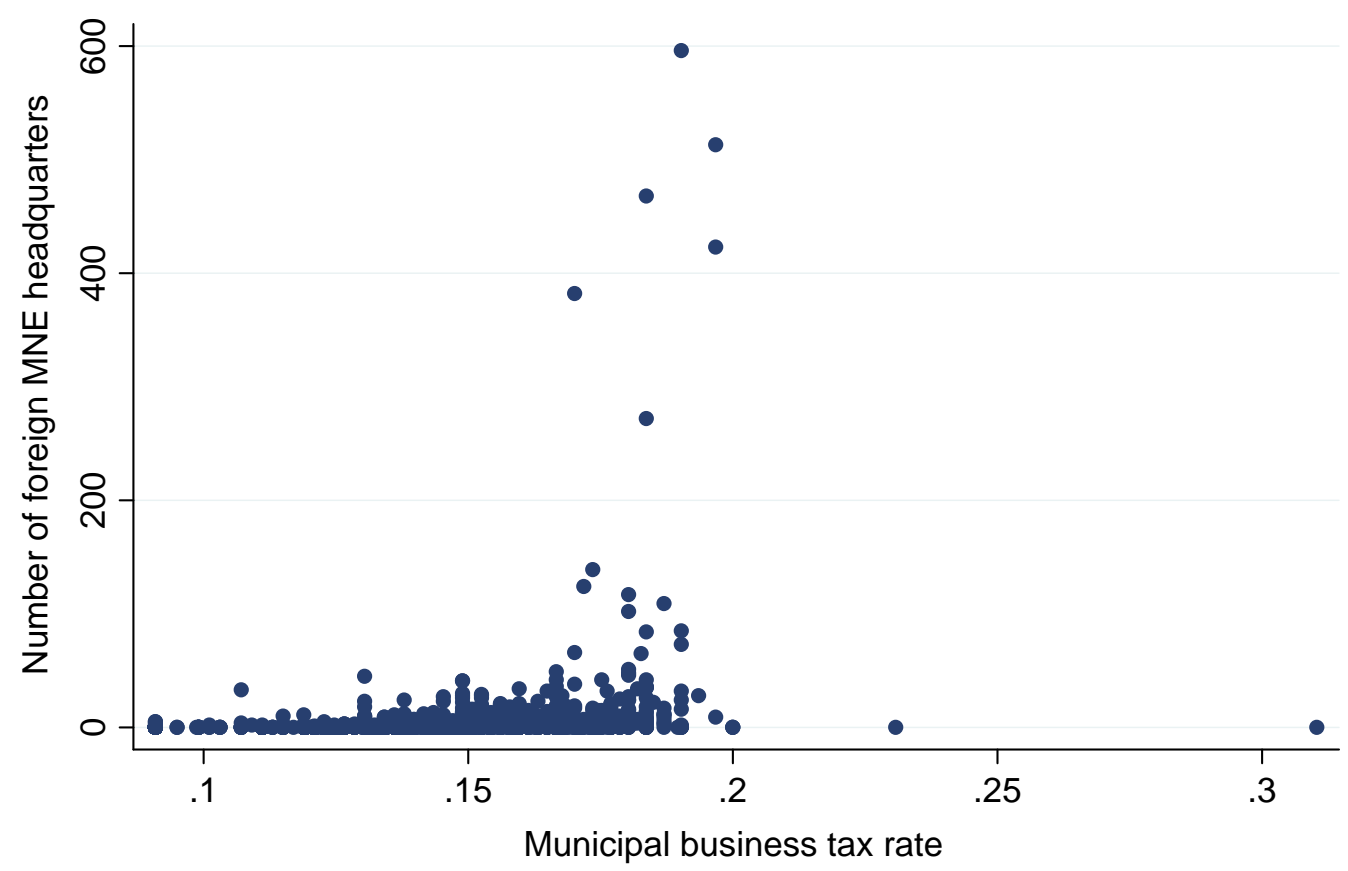


Figure 3b: Foreign MNE headquarters and the business tax rate Municipalities with at least one headquarter

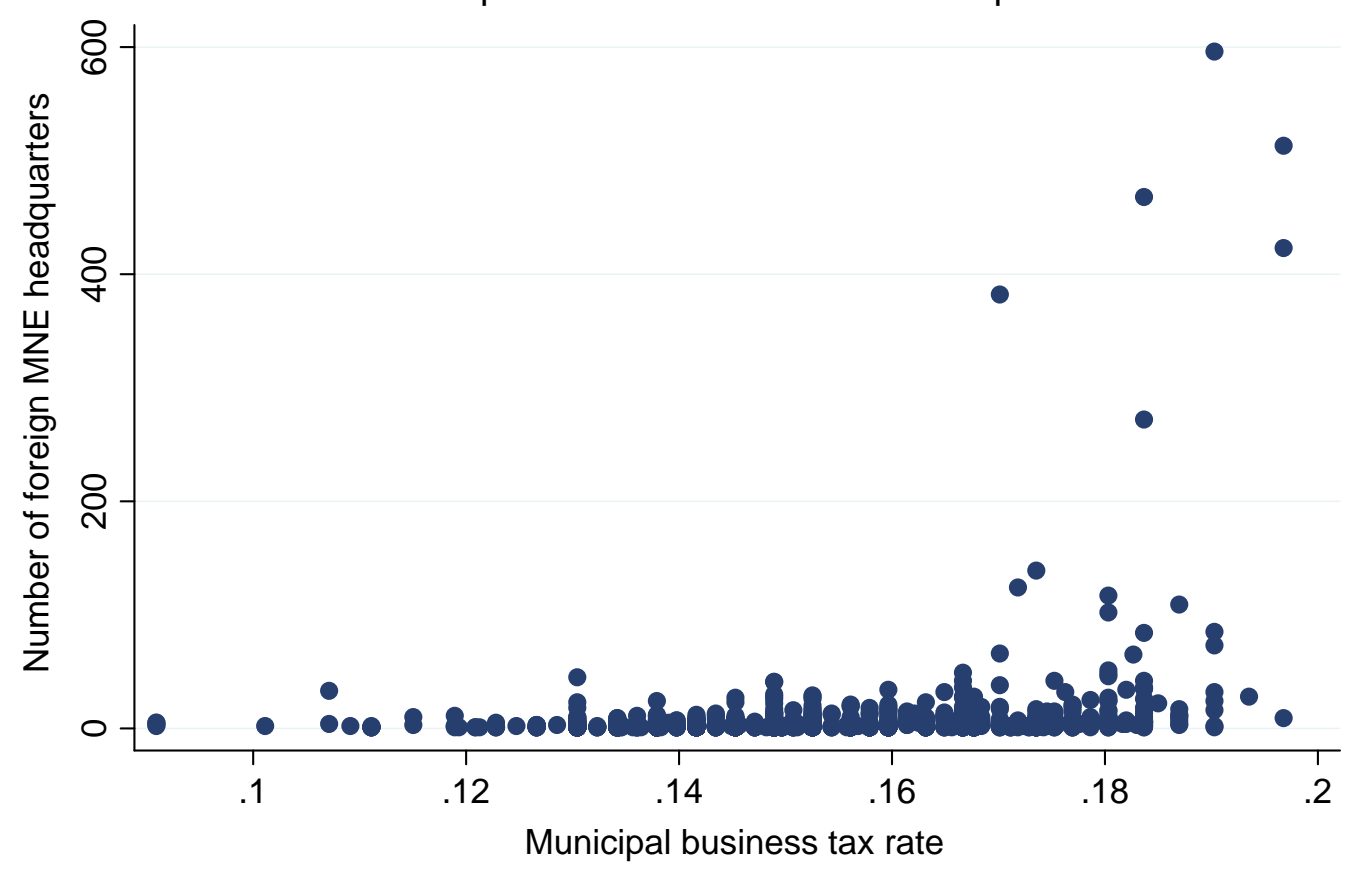

